\title{
Macromolecular composition, productivity and dimethylsulfoniopropionate in Antarctic pelagic and sympagic microalgal communities
}

\author{
Cristin Elizabeth Sheehan ${ }^{1,2}$, Daniel Aagren Nielsen ${ }^{1}$, Katherina Petrou ${ }^{1, *}$ \\ ${ }^{1}$ School of Life Sciences, University of Technology Sydney, Sydney, NSW 2007, Australia \\ ${ }^{2}$ Climate Change Cluster, University of Technology Sydney, Sydney, NSW 2007, Australia
}

\begin{abstract}
Microalgae form the base of the Antarctic marine food web and through their conversion of nutrients into biomass, are the principal source of energy for higher trophic levels. Environmental conditions strongly influence microalgal photophysiology, biochemistry and macromolecular composition, which has implications for the quality and quantity of energy available for transfer through the food web. Here we assessed the photosynthetic performance, biochemical (dimethylsulfoniopropionate; DMSP) and macromolecular composition (lipids, carbohydrates and proteins) of selected diatoms sampled from 2 distinct Antarctic marine environments, namely the late spring bottom sea ice (sympagic) and near-shore ice-free coastal waters (pelagic). The photosynthetic efficiency and photoprotective capacity of the communities differed significantly, and chlorophyll $a$-specific gross primary productivity was 4 -fold greater in the pelagic community. At the community level, pelagic microalgae had the highest DMSP content $\left(1.4 \mathrm{nmol}[\mu \mathrm{g} \mathrm{chl} \mathrm{a}]^{-1}\right)$ and the highest potential rates of DMSP lyase activity $\left(0.87 \mathrm{nmol}[\mu \mathrm{g} \mathrm{chl} \mathrm{a}]^{-1} \mathrm{~h}^{-1}\right)$. Comparisons within each community showed taxon-specific differences in macromolecular composition, which were strongest amongst the sympagic diatoms. Comparing across communities, pelagic diatoms had lower lipid to protein ratios, whereas sympagic diatoms were lipid rich and had significantly higher content of unsaturated fatty acids. These findings show variability in the physiology and nutritional quality of the base of the food web depending on habitat and taxonomic group and emphasise the importance of the sympagic community for providing a concentrated source of high-energy compounds during the pulsed productivity events for key grazers such as krill to survive through long dark winters.
\end{abstract}

KEY WORDS: Southern Ocean · Phytoplankton - Diatoms · Dimethylsulfoniopropionate · Macromolecules · FTIR-microspectroscopy

Resale or republication not permitted without written consent of the publisher

\section{INTRODUCTION}

Marine microalgae form the base of the pelagic food web and are the primary source of macromolecules (lipids, proteins and carbohydrates) in the marine environment (Follows \& Dutkiewicz 2011). As primary producers, microalgae fix carbon through photosynthesis and convert it into biomass which delivers energy to higher trophic levels. Microalgae are strongly influenced by the chemistry of the waters surrounding them and can in turn modify it. For example, marine microalgae make use of available macro- and micronutrients for growth and productivity yet play a vital role in recycling those nutrients via their growth, consumption, exudation of compounds and cell lysis (Buesseler 1998, Garibotti et al. 2003a,b). This bilateral exchange between environment and micro- 
algae is important for nutrient cycling and energy transfer throughout the marine ecosystem. The natural flux of seawater nutrient composition often shapes which species proliferate at any given time or location. Once a species grows to dominate a community, it can have significant influence on local nutrient cycling and biogeochemistry. For example, diatoms are closely linked to the silica cycle (Tréguer \& De La Rocha 2013, Tréguer et al. 2018) and therefore strongly influence surface ocean silicic acid concentrations and carbon export, which in turn affects which species will follow. Similarly, both haptophytes and dinoflagellates are important contributors to the marine sulfur cycle (Keller 1989), producing large amounts of the organic sulfur compound dimethylsulfoniopropionate (DMSP), altering carbon and sulfur available to the microbial community. As such, microalgae invariably alter the conditions around them, allowing for new species to flourish under a different combination of environmental conditions. It is this biological-chemical interaction that results in transitory assemblages in surface waters, a process that underpins marine microbial diversity and phenotypic plasticity, ultimately dictating trophodynamics while enhancing ecosystem resilience (Halsey \& Jones 2015).

The Southern Ocean experiences strong seasonal patterns yet supports highly diverse microalgal communities that are essential for fuelling the abundance of energy-hungry top predators. Southern Ocean microalgae are physiologically plastic and evolutionarily adapted to the seasonal variability over an annual cycle (Gleitz \& Thomas 1992, Morgan-Kiss et al. 2006). They acclimate to fluctuations in light, temperature and nutrients on time scales of minutes to seasons by adjusting their photosynthetic processes (Falkowski \& LaRoche 1991, MacIntyre et al. 2002) and morphology (Villareal \& Fryxell 1983) and by allocating energy into different macromolecular stores (Arrigo 2005, Moore et al. 2013, Halsey \& Jones 2015). Additionally, photophysiological adjustment to temperature, light and nutrient stress are achieved through alterations in light harvesting or photoprotection (Mock \& Hoch 2005, Kropuenske et al. 2009, 2010, Petrou et al. 2010, 2011a,b). Such physiological adjustments are often diatom specific (Petrou et al. 2011a), but different photophysiological strategies also exist between phytoplankton groups, such as diatoms and the ecologically important bloom-forming haptophyte Phaeocystis antarctica (Kropuenske et al. 2009, 2010, Mills et al. 2010). This phenotypic variability underpins marine microalgal diversity, allowing for niche differentiation in space and time (Bowler et al. 2008).

Adaptive strategies used by phytoplankton lead to shifts in the allocation of energy and carbon, specifically the way in which photosynthetically derived carbon is partitioned into different macromolecular pools (Halsey \& Jones 2015, Wagner et al. 2017). Together with community structure, this determines the $\mathrm{C}: \mathrm{N}: \mathrm{P}$ ratio of the microalgal biomass, where functionally, proteins are the reservoir of nitrogen $(\mathrm{N})$, phospholipids and nucleic acids form the stores of phosphorus (P), and the combination of carbohydrates, proteins and lipids defines the cellular carbon (C) pool (Finkel et al. 2016b). However, macromolecular stoichiometry varies between species and across phylogenetic groups (Finkel et al. 2016b), making understanding competitive interactions among species and their role in food webs difficult to disentangle from that of the whole community. Furthermore, the non-equilibrium conditions of these macromolecular stores can have profound effects on food web dynamics and nutrient cycling, where carbon quality influences grazer fitness and organic carbon exudates from phytoplankton fuel the microbial loop (Halsey \& Jones 2015).

Antarctic microalgae exposed to variable temperature, nutrient and salinity regimes have been shown to adjust their lipid stores (Mock \& Kroon 2002a,b, Morgan-Kiss et al. 2006, Sackett et al. 2013). Sea-ice algae grown under low light showed a $50 \%$ increase in an important thylakoid membrane fatty acid that supports the fluidity of the membrane and rate of electron flow in photosystem II (Mock \& Kroon 2002b). The same thylakoid-related fatty acid declined under nitrogen limitation (Mock \& Kroon 2002a); however, nitrogen limitation led to an increase in chloroplast-related phospholipids and storage of triacylglycerols (TAGs), which were identified as key energy reserves in N-limited sea-ice microalgae (Mock \& Kroon 2002a). Using Fourier transform infrared (FTIR) spectroscopy, another study revealed species-specific responses whereby 2 diatom species, Fragilariopsis cylindrus and Chaetoceros simplex, expressed elevated lipid accumulation when exposed to low temperature and high salinity conditions, compared with the diatom Pseudonitzschia subcurvata, which under the same conditions showed minimal macromolecular adjustment (Sackett et al. 2013). Higher lipid to protein ratios were also observed in sea-ice algae when nitrogen was limiting later in the season (Pogorzelec et al. 2017). Taken together, these studies reveal the sig- 
nificant plasticity in lipid metabolism in sea-ice microalgae.

As part of their acclimation strategy, polar microalgae may use temporary energy stores, such as osmolytes (Halsey \& Jones 2015). These strongly reduced, low molecular weight compounds, in addition to providing osmoregulatory function, help to stabilise protein structures and deter grazers, and they may also serve as sinks for NADPH during periods of excess light (Halsey \& Jones 2015). DMSP is one potential osmolyte produced in high concentrations by many microalgal species (Stefels 2000). High levels of DMSP have been measured directly in sea-ice algae (Asher et al. 2011, Galindo et al. 2014, 2016) and along sea-ice edges (Trevena \& Jones 2006, Carnat et al. 2016, Damm et al. 2016, Gabric et al. 2018, Stefels et al. 2018). Similarly, changes in temperature, salinity and light, like those experienced during a sea-ice break out, induce a rapid change in the production of DMSP by the microalgal community, possibly as a stress response (Vance et al. 2013). The abundance and prevalence of DMSP in sea-ice organisms suggest that it might play an important cryoprotective or osmoregulatory role to support exposure to the freezing, hypersaline conditions of their icy habitat (Thomas \& Dieckmann 2002, Lyon et al. 2011).

Changes in environmental conditions have the potential to alter community hierarchies and species succession by affecting seawater chemistry and individual physiologies. These ecological shifts in species composition and cell physiology manifest as modifications to macromolecular reserves (i.e. the community energy stores) and thereby influence food quality and energy transfer capacity. In polar regions, where food availability is low most of the year, optimising nutritional gains during pulsed productivity events (spring/summer) is key to surviving the long darkness. For Antarctic zooplankton, this means storing energy in the form of lipids, either as wax esters or TAGs (Hagen et al. 1996). As such, microalgal macromolecular composition, in particular lipid biosynthesis and accumulation, plays an essential role in determining the growth and survival of Antarctic marine fauna. In this study, we characterised and compared phenotypic traits of microalgae from 2 physico-chemically distinct yet connected Antarctic marine habitats. Specifically, we aimed to describe the community composition, photosynthetic performance, macromolecular composition and sulfur biochemistry of microalgal communities from the open ocean (pelagic) and sea ice (sympagic) environments around Davis Station, Antarctica.

\section{MATERIALS AND METHODS}

\subsection{Sample collection}

Natural microalgal communities were collected from the ice-free coastal open ocean (pelagic) and sea ice (sympagic) environments. Pelagic surface water samples (1-2 m depth) were collected from approximately $1 \mathrm{~km}$ offshore of Davis Station, Prydz Bay $\left(68^{\circ} 34^{\prime} \mathrm{S}, 77^{\circ} 56^{\prime} \mathrm{E}\right)$ on 19 November 2014. Seawater was collected by helicopter using a Bambi Bucket and transported to shore where it was stored for $2 \mathrm{~d}$ in 6501 tanks $(\mathrm{n}=6)$ for a separate ecosystem experiment (see Deppeler et al. 2018, Petrou et al. 2019). The community was maintained at $\sim 0.0 \pm$ $0.5^{\circ} \mathrm{C}$ under very low light $\left(<1 \mu \mathrm{mol}\right.$ photons $\left.\mathrm{m}^{-2} \mathrm{~s}^{-1}\right)$ prior to subsampling and analysis.

Sympagic algae were obtained from 3 separate ice cores taken from the annual pack ice in Prydz Bay, Davis Station $\left(68^{\circ} 33^{\prime} \mathrm{S}, 77^{\circ} 57^{\prime} \mathrm{E}\right)$, approximately $1.5 \mathrm{~km}$ from the pelagic sampling site, on 21 November 2014. Snow depth at the time of sampling was minimal $(<5 \mathrm{~cm})$ and cores were obtained using an ice auger (220 mm $\varnothing)$. Sympagic microalgae were collected by shaving off the bottom $10 \mathrm{~cm}$ of the $1.5 \mathrm{~m}$ ice cores and the ice shavings melted in the dark at $\sim 0.0^{\circ} \mathrm{C}$ for $24 \mathrm{~h}$ with regular additions of filtered seawater $(0.22 \mu \mathrm{m})$ to prevent the salinity of the water dropping too low (aimed to keep at or above 30) and potentially damaging the cells, and the total volume was recorded to correct for dilution. Salinity and temperature were measured using a standard benchtop conductivity meter and hand-held thermometer.

\subsection{Physiological measurements}

The photophysiological condition of the microalgal communities was determined using chlorophyll a (chl a) fluorescence measured with a pulse amplitude modulated fluorometer (Water PAM, Walz). Briefly, a $3 \mathrm{ml}$ aliquot was dark adapted for $30 \mathrm{~min}$ before a steady state light curve consisting of 5 independent light steps of $5 \mathrm{~min}$ each $(130,300,600,975$ and $1425 \mu \mathrm{mol}$ photons $\mathrm{m}^{-2} \mathrm{~s}^{-1}$ for pelagic communities; and $40,92,206,435$ and $1425 \mu \mathrm{mol}$ photons $\mathrm{m}^{-2} \mathrm{~s}^{-1}$ for sympagic communities) with a saturating pulse of light (>3000 $\mu \mathrm{mol}$ photons $\mathrm{m}^{-2} \mathrm{~s}^{-1}, 0.8 \mathrm{~s}$, intensity 8) applied after $5 \mathrm{~min}$, was performed. From these data, the following photophysiological parameters were determined: maximum quantum yield $\left(F_{\mathrm{V}} / F_{\mathrm{M}}\right)$, effective quantum yield $\left(\Delta F / F_{M}{ }^{\prime}\right)$ and non-photochemical quenching (NPQ). Relative electron transport rates 
(rETR) were calculated as the product of $\Delta F / F_{M}$ (where $\Delta F$ is the difference between minimum and maximum fluorescence and $F_{\mathrm{M}}$ is the maximum light-adapted fluorescence) and irradiance and data fitted according to the double exponential function described by Ralph \& Gademann (2005) to derive the photophysiological parameters maximum rETR $\left(\mathrm{rETR}_{\max }\right)$, light utilisation efficiency $(\alpha)$ and minimum saturating irradiance $\left(E_{k}\right)$. All photophysiological measurements were performed inside an incubator set at $0.0 \pm 0.5^{\circ} \mathrm{C}$.

Using custom-built oxygen vials connected to a 4-channel fibre-optic oxygen meter (Pyroscience FireSting $\mathrm{O}_{2}$ ), net production and respiration were measured. The system consisted of $5.1 \mathrm{ml}$ glass vials $(\mathrm{n}=4)$ with oxygen sensor spots (Pyroscience) attached on the inside of the vial using non-toxic silicon glue. Optodes were calibrated according to the manufacturer's protocol immediately prior to measurements using a freshly prepared sodium thiosulfate solution $(10 \% \mathrm{w} / \mathrm{w})$ and agitated filtered seawater $(0.2 \mu \mathrm{m})$ at experimental temperature for 0 and $100 \%$ air saturation values, respectively. To obtain dark respiration and net photosynthesis rates, each vial was filled with either pelagic or sympagic samples $(n=4)$ and then sealed. All vials were stirred continuously using Teflon cuvette stirrers to allow homogeneous mixing of gases within the system. To improve the signal-to-noise ratio, seawater from the pelagic community was concentrated $(8 x)$ above a $0.8 \mu \mathrm{m}$ polycarbonate membrane filter (Poretics, Thomas Scientific) under gentle vacuum. While in the dark, respiration rates were recorded until a linear rate could be obtained, and then samples were exposed to light $\left(144 \mu \mathrm{mol}\right.$ photons $\left.\mathrm{m}^{-2} \mathrm{~s}^{-1}\right)$ for several minutes until a steady net oxygen production was obtained. Respiration and photosynthesis rates were determined from the slope of the change of oxygen concentration in the vials and gross productivity calculated by summing the absolute value of respiration and net production rates. All measurements were conducted at $0.0 \pm 0.5^{\circ} \mathrm{C}$. Additionally, aliquots (30-100 $\mathrm{ml}$ of the pre-concentrated sample for pelagic community and $15 \mathrm{ml}$ of original sample for the sympagic communities) were filtered onto $25 \mathrm{~mm}$ GF/F filters (Whatman) and flash frozen in liquid nitrogen for later determination of chl a concentration for normalisation of data. Pigments were extracted in $90 \%$ acetone and incubated at $4^{\circ} \mathrm{C}$ in the dark for $24 \mathrm{~h}$. Chlorophyll concentration was determined using a spectrophotometer (Cary50, Varian) and calculated using the equations of Jeffrey \& Humphrey (1975), as modified by Ritchie (2006).

\subsection{Community composition}

The pelagic phytoplankton community was identified via light microscopy and enumerated using an Utermöhl chamber (see Hancock et al. 2018). Briefly, seawater samples $(960 \mathrm{ml})$ were fixed in Lugol's iodine and left to sediment at $4^{\circ} \mathrm{C}$ for $4 \mathrm{~d}$ before aspirating the top $750 \mathrm{ml}$ and transferring the remainder into a measuring cylinder, where cells were allowed to settle and a final volume of $20 \mathrm{ml}$ retained. Between 2 and $10 \mathrm{ml}$ of concentrated sample were added to an Utermöhl cylinder (Hydro-Bios), and cells were allowed to settle overnight before counting. Due to variability in cell sizes, a stratified counting method was employed, using 200× for cells greater than $20 \mu \mathrm{m}$ and $400 \times$ for those less than $20 \mu \mathrm{m}$. The sympagic community was investigated via light microscopy using a nannoplankton counting chamber (PhycoTech). Fixed samples were loaded under the cover slip and allowed to settle before counting and identifying cells within the entire chamber. Cells were identified to species where possible, but in cases of uncertainty, cells were either categorised to genus or placed into broad taxonomic or functional groups.

\subsection{Quantification of DMSP in pelagic and sympagic communities}

For transport of DMSP samples from Antarctica back to Australia, a methanol preservation method (Tapiolas et al. 2013) was followed. Briefly, samples $(50 \mathrm{ml})$ from each community were centrifuged at low RPM to form a loose pellet, and the overlying seawater was carefully removed. The pellet was then resuspended in $10 \mathrm{ml}$ of methanol $(100 \%)$, placed in a sonication ice bath for $30 \mathrm{~min}$ and transported and stored at $3^{\circ} \mathrm{C}$ until further processing. Prior to analysis, the methanol extract was dried using a rotary evaporator (Buchi Rotavapor R-210, attached vacuum controller V-850 and heating bath B-491) and the dried extract resuspended in $3 \mathrm{ml}$ of ultrapure water and vortexed to completely solubilise the compounds. Sub-samples were aliquoted into gas-tight vials containing $\mathrm{NaOH}$ and immediately sealed, agitated and then left in the dark to react for $12 \mathrm{~h}$ at room temperature. Quantification of total DMSP (DMSPt) was carried out after conversion of DMSP to DMS via hydrolysis with $\mathrm{NaOH}$. Measurements were carried out using a gas chromatograph (GC-2010, Shimadzu) coupled with a flame photometric detector set at $180^{\circ} \mathrm{C}$ with hydrogen and instrument grade air flow rate set at 40 and $60 \mathrm{ml} \mathrm{min}^{-1}$, respectively. 
For each measurement, $500 \mu \mathrm{l}$ of sample headspace were injected into the GC, and DMS was eluted on a capillary column $(30 \mathrm{~m} \times 0.32 \mathrm{~mm} \times 5 \mu \mathrm{m})$ set at $120^{\circ} \mathrm{C}$ using helium as the carrier gas set at a con-

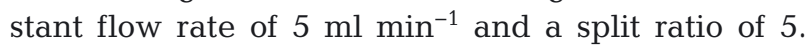
DMSP was normalised to chl a.

\subsection{DMSP lyase activity (DLA) of pelagic and sympagic communities}

Measurements for DLA were performed as described by Harada et al. (2004). Low incubation and measuring temperatures $\left(\sim 0^{\circ} \mathrm{C}\right)$ were used throughout the analysis in order to obtain ecologically relevant rates of lyase activity. Briefly, $15 \mathrm{ml}$ of sample were gently filtered onto a $\mathrm{GF} / \mathrm{F}$ filter, flash frozen in liquid $\mathrm{N}_{2}$ and stored at $-80^{\circ} \mathrm{C}$ until analysis. Prior to analysis, filters were thawed slowly on ice and then transferred facedown into a gas-tight glass vial in $1 \mathrm{ml}$ of $\mathrm{pH} 8.2$ TRIS buffer, capped with a rubber stopper and vortexed for $10 \mathrm{~s}$. After $20 \mathrm{~min}$ of incubation in iced water, $20 \mu \mathrm{l}$ of DMSP-HCl (Sigma Aldrich) were added to a final concentration of $5 \mathrm{mM}$, and the vial was sealed and crimped. The vial was vortexed vigorously for $10 \mathrm{~s}$ and returned to the iced water; the timer was then started and $100 \mu \mathrm{l}$ of headspace ( 2\% of headspace volume) were immediately extracted using a gas tight syringe and injected onto the gas chromatograph for quantification of DMS (as described above). DMS production was monitored over time (up to total $\sim 45 \mathrm{~min}$ ) with 4-5 sequential measurements with the exact time of headspace removal recorded. The obtained DMS production rate was corrected for the abiotic cleavage activity found in the buffer controls.

\subsection{Macromolecular composition}

To determine the macromolecular composition of pelagic and sympagic diatom species, Synchrotronbased FTIR microspectroscopy was conducted on formalin-fixed ( $2 \%$ v/v final concentration) cells. Given that the sympagic community only contained diatoms, only diatoms from the pelagic community were chosen; this allowed for better taxonomic comparison between the 2 habitats. Individual cells were analysed in hydrated form by pipetting fixed sample directly onto a calcium fluoride window (0.3 mm thick), which was placed within a compression chamber to prevent evaporation before and during measurements (Tobin et al. 2010). Spectral data were collected on the Infrared Microspectroscopy Beamline at the Australian
Synchrotron, Melbourne, in November 2015. Spectra were acquired over the measurement range 4000$800 \mathrm{~cm}^{-1}$ with a Vertex 80v FTIR spectrometer (Bruker Optics) in conjunction with an IR microscope (Hyperion 2000, Bruker) fitted with a mercury cadmium telluride detector cooled with liquid nitrogen. The microscope was connected to a computer-controlled microscope stage contained within a box purged with dehumidified air to reduce water-vapour interference. Co-added interferograms $(n=64)$ were collected at a wavenumber resolution of $6 \mathrm{~cm}^{-1} \mathrm{~s}$. Measurements were made in transmission mode at an aperture size of $5 \times 5 \mu \mathrm{m}$ (measuring area), allowing for measurements of individual cells. Spectral acquisition and instrument control were achieved using Opus 6.5 software (Bruker).

\subsection{Data analysis}

To compare photosynthetic parameters, oxygen production rates, particulate DMSP and DLA between pelagic and sympagic communities, a 1-way ANOVA was used at a significance level of $\alpha=0.05$. A priori tests for the assumptions of normal distribution and homogeneity of variance were conducted using the Kolmogorov-Smirnov and Levene's tests, respectively. Infrared spectral data were analysed using custom made scripts in R 3.6 (R Development Core Team 2018). The regions of 3050-2800 and 1770$1100 \mathrm{~cm}^{-1}$, which contain the major biological bands, were selected for analysis. Data were smoothed (4 points either side) and second derivative (third-order polynomial) transformed using the Savitzky-Golay algorithm from the 'prospectr' package (Stevens \& Ramirez-Lopez 2013) and then normalised using the single normal variate method. To investigate the macromolecular signature of each species and look for consistencies within habitats, derived and normalised spectra were plotted using principal component analysis (PCA). Macromolecular content for individual species was estimated based on integrating the area under each assigned peak. This provides a relative approximation of metabolite content according to the Beer-Lambert Law that assumes a direct relationship between absorbance and analyte concentration (Wagner et al. 2010). Integrated peak areas of populations of individual cell profiles were tested for speciesspecific differences using a 1-way ANOVA with a Tukey's HSD post hoc test for comparisons between species. Mean macromolecular content for each species was tested for site differences by 1-way ANOVA. All statistical tests were performed in $\mathrm{R}$. 


\section{RESULTS}

\subsection{Habitat characteristics and community structure}

The physical characteristics varied between the 2 habitats, where the pelagic environment was characterised by a salinity of $\sim 30$ and water temperature of $1.1^{\circ} \mathrm{C}$, while the bottom sea-ice community temperature was $-1.4^{\circ} \mathrm{C}$ and the salinity ranged between 16 and 29 upon the ice melting. Average total cell abundance was $3.48 \times 10^{5}$ cells $1^{-1}$ for the pelagic community, while almost an order of magnitude higher abundances $\left(2.06 \times 10^{6}\right.$ cells $\left.\mathrm{l}^{-1}\right)$ were recorded for the sympagic community. The pelagic community was the most diverse, with 29 taxa consisting of 11 orders and 19 families, and was numerically domi- nated by small flagellates (43\%) and the haptophyte Phaeocystis spp., which accounted for more than a third of the community $(31.4 \%)$. Diatoms were the most diverse class, represented by 19 taxa, while their combined abundance accounted for $\sim 21 \%$ of the community. However, given that diatoms are generally larger than many of the most numerically abundant taxa (i.e. Phaeocystis antarctica and flagellates), it can be assumed that their overall contribution to community biomass and therefore influence in the community is greater than suggested by their numerical abundance. Dinoflagellates and cryptophytes were also present, but in lower numbers, contributing 5 and $12 \%$, respectively (Fig. 1). The sympagic community was less diverse, comprised predominantly of 4 diatom taxa: Odontella sp., which accounted for $47 \%$ of the population, Entomoneis

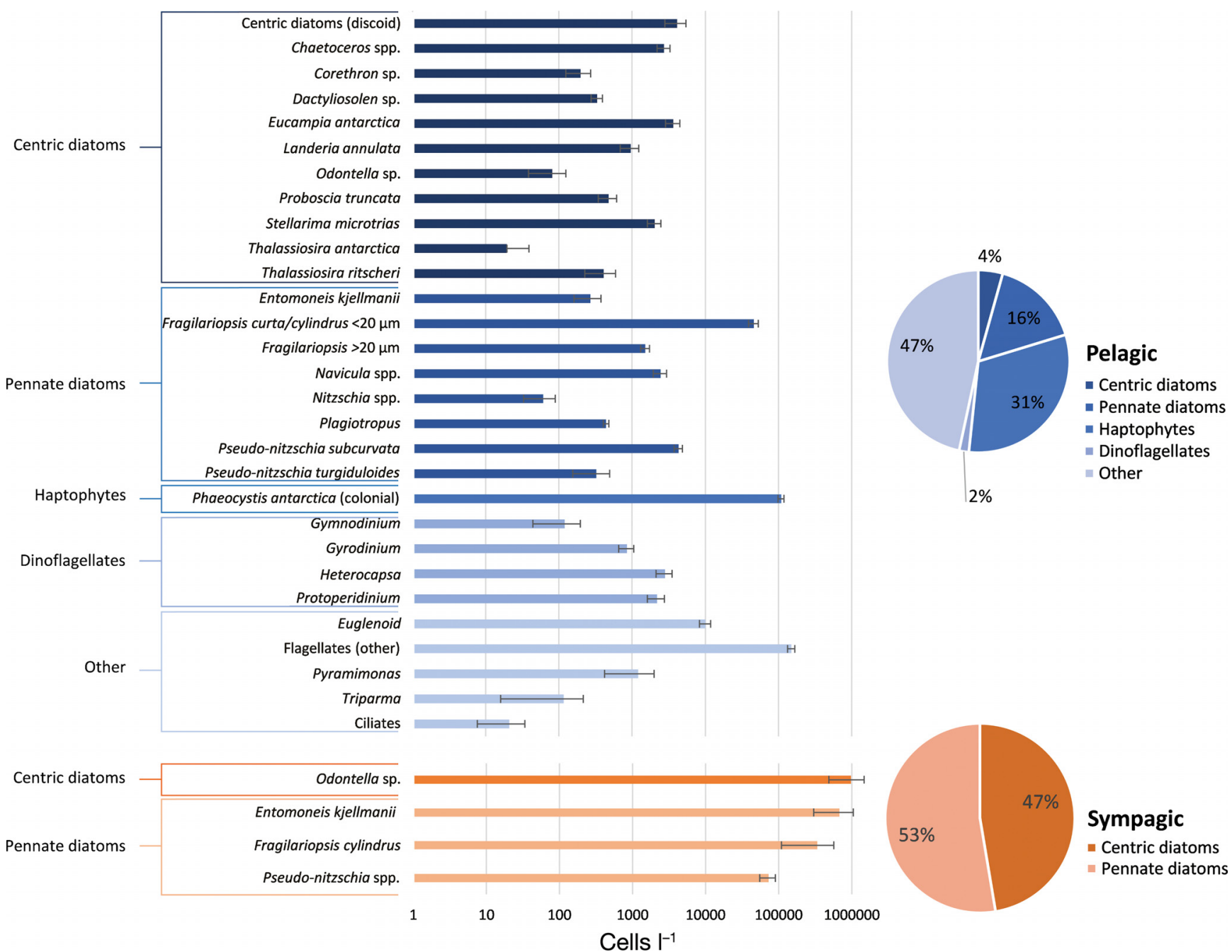

Fig. 1. Community composition and mean \pm SEM cell abundance (cells $\left.\mathrm{l}^{-1}\right)$ from natural Antarctic microalgal communities $(\mathrm{n}=$ 3). Blue: pelagic, orange: sympagic. Pie charts illustrate proportional contribution of taxonomic groupings. Note the log scale on the $x$-axis 
kjellmanii (33\%), Fragilariopsis cylindrus (16\%) and several species from the genus Pseudo-nitzschia $(\sim 3 \%)$. The notable absence of non-diatom taxa (flagellates and ciliates) from the sea-ice samples was unexpected, as these groups can often make up large fractions of the sea-ice community (Garrison \& Buck 1986). While every attempt was made to keep salinity levels as close to 30 as possible during melting, the periods of lowered salinity may have caused excessive osmotic stress in the non-diatom taxa, resulting in their loss from the sample and a bias towards diatoms in our sympagic community (Garrison \& Buck 1986).

\subsection{Photophysiology and productivity}

Photophysiological responses differed between the 2 communities, with significantly higher maximum quantum yield $\left(F_{\mathrm{V}} / F_{\mathrm{M} i} F_{1,4}=66.5, \mathrm{p}=0.001\right)$ in pelagic communities (Table 1), as well as higher effective quantum yields ( $\Delta F / F_{\mathrm{M}^{\prime}}$; Fig. 2A) and rETR (Fig. 2B). The sympagic community showed greater sensitivity to high irradiance, where $\Delta F / F_{\mathrm{M}}$ ' declined more rapidly at lower light levels and rETR values were generally lower than those of the pelagic community (Fig. 2A,B). There were, however, no differences in the light utilisation efficiency $(\alpha)$ or minimum saturating irradiance $\left(E_{k}\right)$ between the 2 communities (Table 1). Higher maximum rETRs $\left(\mathrm{rETR}_{\max } F_{1,4}=\right.$ $28.2, \mathrm{p}=0.006$ ), were measured in the pelagic community (Table 1). No difference was detected in the NPQ in response to high light between the 2 communities (Fig. 2C). Gross primary productivity corresponded with the photophysiological data, where the

Table 1. Photosynthetic parameters $\pm \mathrm{SD} . F_{\mathrm{V}} / F_{\mathrm{M}}$ : maximum quantum yield of PSII; $\alpha$ : light utilisation efficiency; rETR $_{\max }$ : relative maximum electron transport rate; $E_{k}$ : minimum saturating irradiance $\left(\mu \mathrm{mol}\right.$ photons $\left.\mathrm{m}^{-2} \mathrm{~s}^{-1}\right)$. Asterisk $\left({ }^{*}\right)$ indicates significant ANOVA results $(\mathrm{p}<0.05)$

\begin{tabular}{|lcc|}
\hline & Pelagic & Sympagic \\
\hline$F_{\mathrm{V}} / F_{\mathrm{M}}{ }^{*}$ & $0.765 \pm 0.026$ & $0.566 \pm 0.033$ \\
$\alpha$ & $0.65 \pm 0.15$ & $0.50 \pm 0.01$ \\
$\mathrm{rETR}_{\max }{ }^{*}$ & $207 \pm 27.0$ & $76 \pm 33$ \\
$E_{k}$ & $334 \pm 99$ & $152 \pm 66$ \\
\hline
\end{tabular}

pelagic community had significantly higher gross primary productivity $\left(F_{1,6}=237, \mathrm{p}<0.0001\right)$ than the sympagic community at 0.44 and $0.12 \mu \mathrm{mol} \mathrm{O}_{2} \mathrm{mg}$ chl $a^{-1} \mathrm{~s}^{-1}$, respectively (Fig. 2D).

\subsection{DMSP content and lyase activity}

Chl a normalised DMSP content was higher in the pelagic community $\left(F_{1,4}=10.43, \mathrm{p}=0.032\right)$ at ratios of $3.43 \mathrm{nmol}(\mu \mathrm{g} \mathrm{chl} \mathrm{a})^{-1}$ (Fig. 3A), more than 12 times the ratio found in the sympagic $(0.28 \mathrm{nmol}[\mu \mathrm{g}$

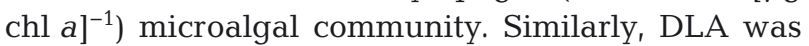
higher in the pelagic community $\left(F_{1,3}=245, \mathrm{p}=\right.$ $0.0005)$, with rates of $1.96 \mathrm{nmol}$ DMS $\left(\mu \mathrm{g} \mathrm{chl} a^{-1}\right) \mathrm{h}^{-1}$, compared with $0.042 \mathrm{nmol}$ DMS ( $\left.\mu \mathrm{g} \mathrm{chl} a^{-1}\right) \mathrm{h}^{-1}$ for the sympagic community (Fig. 3B).

\subsection{Macromolecular content}

Normalised infrared absorbance spectra showed typical bands associated with microalgal samples, with clear distinction of community profiles based on species composition. The second-derivative spectra of the selected biologically relevant regions revealed the specific absorbance bands representing key macromolecules of interest, from which a total of 10 bands with unequivocal band assignments were selected for comparison across environments (Table 2). Representative taxa within habitats were analysed to obtain species-specific differences that underpin community macromolecular profiles. In the open ocean, this consisted of 4 diatom taxa (Chaetoceros, Fragilariopsis, Stellarima microtrias and Thalassiosira antarctica), while the sea-ice community was represented by 3 diatoms (E. kjellmanii, Odontella sp. and $F$. cylindrus). PCA of the peak areas of selected spectral bands for all species from both habitats showed a tight clustering of pelagic species, while species from the sea ice were spread along both PC axes (Fig. 4A). The dominant effect along PC-1, which explained $39.6 \%$ of the variation, was associated with differences in saturated fatty acids and lipids, both of which were higher in the sea-ice algae E. kjellmanii and Odontella sp., while the main effect along PC-2, explaining $24.5 \%$ of the variance, was mostly attributed to differences in cellular protein, unsaturated lipids and carboxylates (Fig. 4A).

Within the pelagic species, PCA revealed that the dominant effect was associated with distinct profiles of Fragilariopsis sp. and Chaetoceros sp. explaining $37.1 \%$ of variation (PC-1), while PC-2 was associated with the spectral profiles of the 2 discoid centric diatoms $S$. microtrias and $T$. antarctica, explaining $22.7 \%$ of the variation (Fig. 4B). The macromolecules of greatest influence, driving variability along PC-1, were saturated fatty acids and lipids (bands 2920 and $2850 \mathrm{~cm}^{-1}$ ), which were higher in Fragilariopsis than 

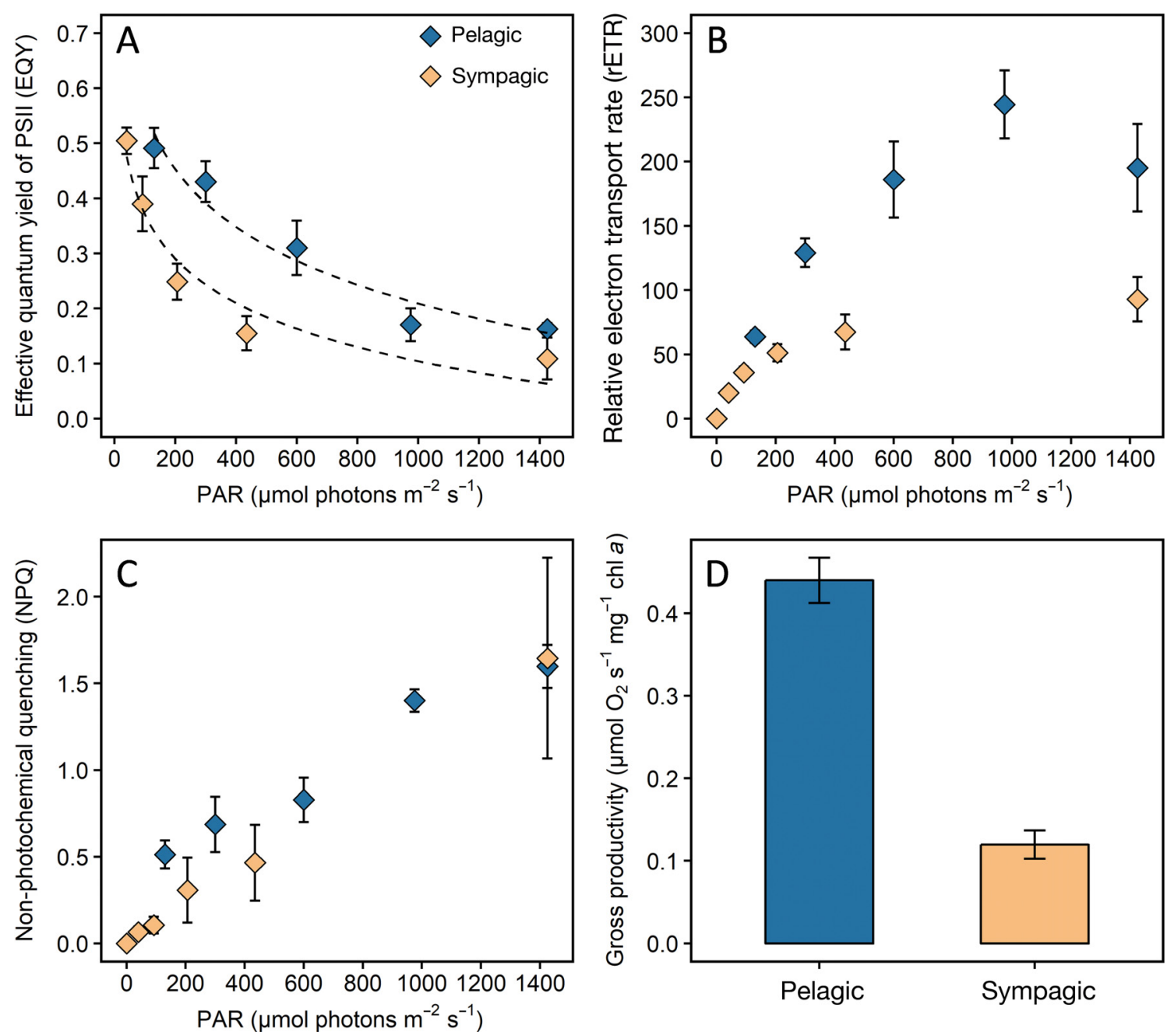

Fig. 2. Photophysiology and gross productivity for Antarctic pelagic (blue) and sympagic (orange) microalgal communities. (A) Effective quantum yield (EQY) of PSII $(\mathrm{n}=3$ ). (B) Relative electron transport rate (rETR, $\mathrm{n}=3$ ). (C) Non-photochemical quenching $(N P Q, n=3)$. (D) Gross primary productivity $(n=3)$. Data represent mean $\pm S E$. Stippled grey lines represent fits of logarithmic regressions
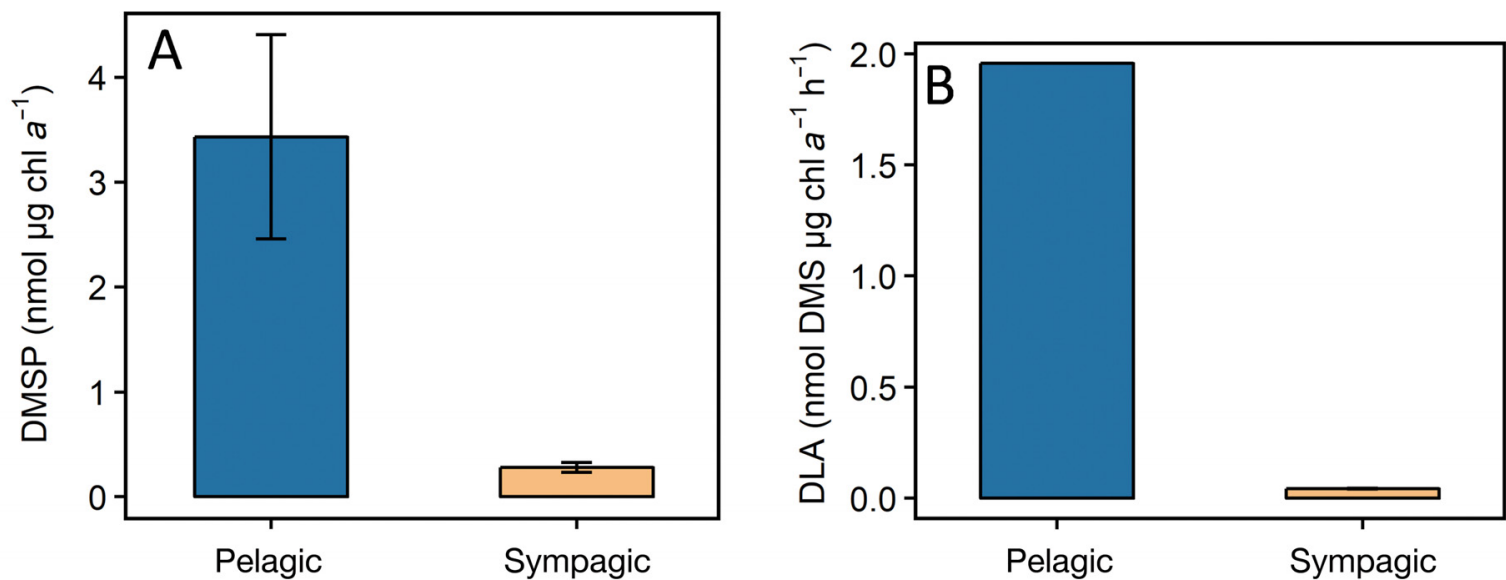

Fig. 3. (A) DMSP content (nmol $[\mu \mathrm{g} \mathrm{chl} a]^{-1}$ ) and (B) DMSP lyase activity (DLA; nmol DMS $[\mu g \text { chl } a]^{-1} \mathrm{~h}^{-1}$ ) for Antarctic pelagic (blue) and sympagic (orange) microalgal communities. Data represent the mean \pm SE $(n=3)$. For pelagic DLA, data represent the mean of $n=2$ 
Table 2. Infrared (IR) band assignments of IR spectra. $v_{a s}$ : asymmetrical stretch $v_{\mathrm{s}}$ : symmetrical stretch; $\delta_{\mathrm{as}}$ : asymmetrical deformation (bend); $\delta_{\mathrm{s}}$ : symmetrical deformation (bend)

\begin{tabular}{|c|c|c|}
\hline $\begin{array}{l}\text { Wavenumber } \\
\left(\mathrm{cm}^{-1}\right)\end{array}$ & Band assignment & Reference \\
\hline$\sim 3015$ & $v(\mathrm{C}-\mathrm{H})$ of cis-alkene $-\mathrm{HCCH}-$, from unsaturated fatty acid & Vongsvivut et al. (2012) \\
\hline$\sim 2965$ & $v_{\text {as }}(\mathrm{C}-\mathrm{H})$ from methyl $\left(-\mathrm{CH}_{3}\right)$, from saturated fatty acids (CH-stretch II) & Vongsvivut et al. (2012) \\
\hline$\sim 2920$ & $v_{\text {as }}(\mathrm{C}-\mathrm{H})$ from methylene $\left(-\mathrm{CH}_{2}\right)$, from saturated fatty acids & Vongsvivut et al. (2012) \\
\hline$\sim 2850$ & $v_{\mathrm{s}}(\mathrm{C}-\mathrm{H})$ from methylene $\left(-\mathrm{CH}_{2}\right)$, from saturated fatty acids & Vongsvivut et al. (2012) \\
\hline$\sim 1745$ & $\begin{array}{l}v(\mathrm{C}=\mathrm{O}) \text { of ester functional groups, from membrane lipids and fatty acids - } \\
\text { ester carbonyls }\end{array}$ & $\begin{array}{l}\text { Murdock \& Wetzel (2009), } \\
\text { Vongsvivut et al. (2012) }\end{array}$ \\
\hline$\sim 1545$ & $\delta(\mathrm{N}-\mathrm{H})$ associated with proteins (amide II band) & Giordano et al. (2001) \\
\hline$\sim 1475$ & $\delta_{\text {as }}\left(\mathrm{CH}_{3}\right)$ and $\delta_{\text {as }}\left(\mathrm{CH}_{2}\right)$ of proteins (carboxylic group) - free amino acids & $\begin{array}{l}\text { Giordano et al. (2001), } \\
\text { Murdock \& Wetzel (2009) }\end{array}$ \\
\hline$\sim 1375$ & $\delta_{\mathrm{s}}\left(\mathrm{CH}_{3}\right)$ and $\delta_{\mathrm{s}}\left(\mathrm{CH}_{2}\right)$ of proteins, and $v_{\mathrm{s}}(\mathrm{C}-\mathrm{O})$ of $\mathrm{COO}^{-}$groups (carboxylic group) & Giordano et al. (2001) \\
\hline$\sim 1175$ & $v(\mathrm{C}-\mathrm{O}-\mathrm{C})$ of polysaccharides (carbohydrates) & Giordano et al. (2001) \\
\hline
\end{tabular}
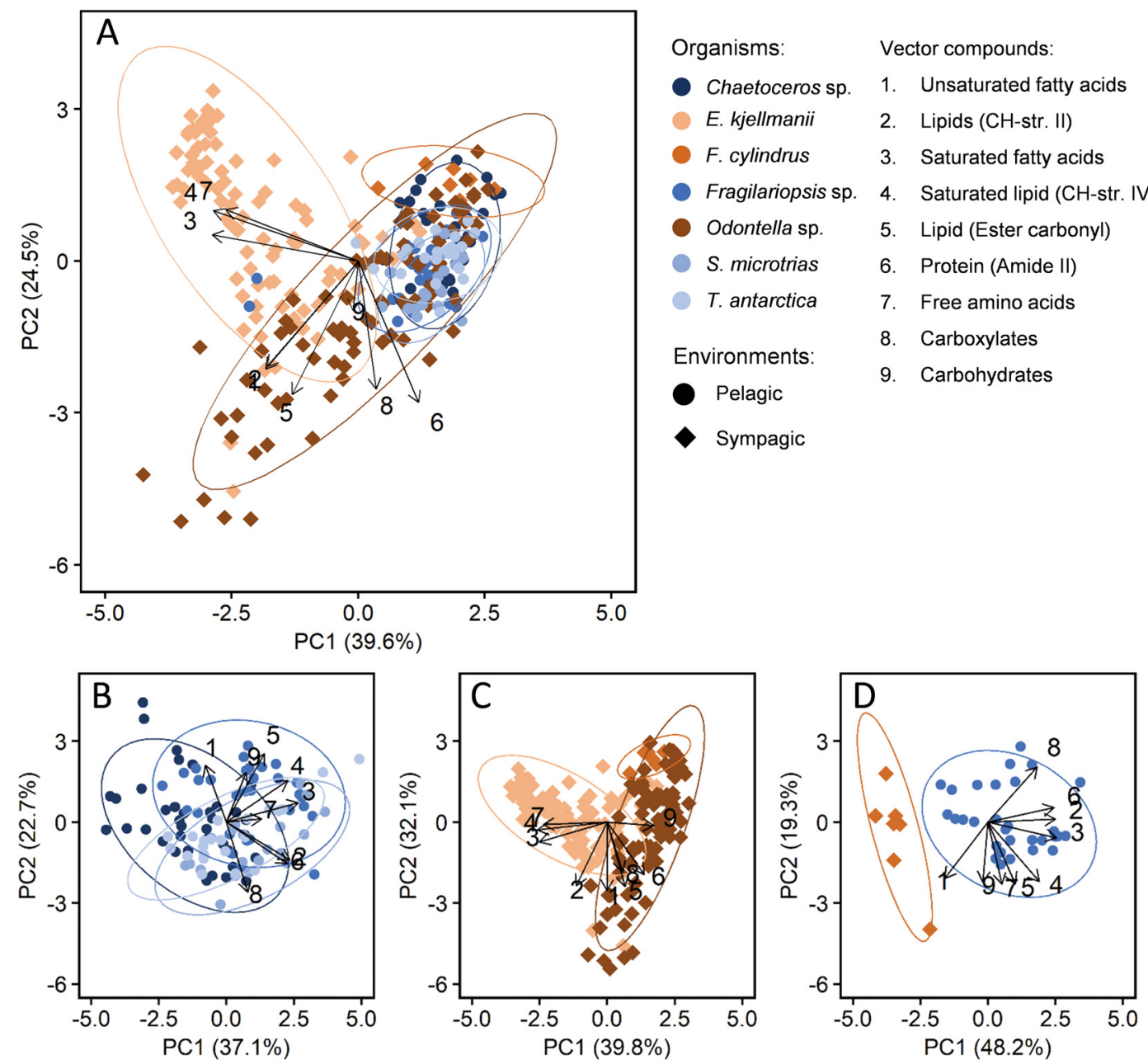

Fig. 4. Macromolecular composition of representative Antarctic pelagic and sympagic microalgal communities. Scores plots of the integrated peak areas of the 9 macromolecules for (A) all diatom species, (B) 4 diatom species from the pelagic environment (Chaetoceros sp., Fragilariopsis sp., Stellarima microtrias and Thalassiosira antarctica), (C) 3 diatom species from the sympagic environment (Entomoneis kjellmanii, F. cylindrus and Odontella sp.) and (D) inter-genera comparison between Fragilariopsis sp.

from the pelagic environment and F. cylindrus from the sympagic environment. Diamonds: sympagic, Circles: pelagic 
the other pelagic species. The second strongest response, represented by deviations along PC-2, were driven by amide II and carboxylates, which were highest in the centric diatoms, S. microtrias and $T$. antarctica, while Chaetoceros and Fragilariopsis seemed to contain relatively more carbohydrates and unsaturated fatty acids than the 2 discoid centric diatoms (Fig. 4B).

The main drivers on sympagic species profiles $(E$. kjellmanii, Odontella sp. and F. cylindrus) underpinning the variability explained by PC-1 (39.8\%) were saturated lipids, fatty acids and free amino acids, which were more abundant in E. kjellmanii, and carbohydrates, which were highest in the other 2 diatoms. Variability explained by PC-2 $(32.1 \%)$ was driven by unsaturated fatty acids and ester carbonyls, which were lowest in F. cylindrus and highest in a sub-population of Odontella sp., and proteins, which were greatest in E. kjellmanii (Fig. 4C).

Comparing within the same genus, Fragilariopsis from the pelagic environment was higher in proteinrelated compounds and saturated fatty acids and lipids, while Fragilariopsis from the sea ice had a higher proportion of carbohydrates and unsaturated fatty acids, explaining $48.2 \%$ of the variation along PC-1 and $19.3 \%$ along PC-2 (Fig. 4D).

Using the integrated peak areas of individual wavebands for each species, we were able to differentiate species-specific variability in macromolecular content and determine whether there were any consistencies across sites (Fig. 5). Carbohydrates varied significantly across species, with $S$. microtrias and $T$. antarctica having lower (Tukey's HSD, $\mathrm{p}<0.001$ and $\mathrm{p}<0.003$, respectively) carbohydrate content than all other species (Fig. 5A). Only minor differences were detected in median carboxylate content between species, where E. kjellmanii was significantly lower than the 2 largest diatoms Odontella sp. and $S$. microtrias $(\mathrm{p}<0.001$ for both; Fig. 5B). Free amino acids were significantly higher in E. kjellmanii $(\mathrm{p}<$ 0.0001) than all other species (Fig. 5C), which showed no variation.

The $\mathrm{C}-\mathrm{H}$ stretch, associated with lipids, was lower in F. cylindrus than all other species $(\mathrm{p}<0.003$ for all comparisons), while E. kjellmanii had the highest relative content, significantly greater than all species ( $p<0.024$ for all comparisons) except $S$. microtrias and T. antarctica (Fig. 5D). For the ester carbonyls, which represent the lipid fraction, the sympagic algae were generally higher than the pelagic, with Odontella sp. having the highest lipid content of all species ( $\mathrm{p}<0.0001$ for all comparisons). This was followed by E. kjellmanii, which had lipid content sig- nificantly greater ( $\mathrm{p}<0.018$ for all comparisons) than the 3 pelagic centric diatoms (Chaetoceros sp., $S$. microtrias and $T$. antarctica). The 2 Fragilariopsis species were intermediates in their lipid content and not different from each other (Fig. 5E). The dominant protein band, amide II, was higher in the 2 discoid centric diatoms from the pelagic environment, $S$. microtrias and T. antarctica, than all of the sympagic species $(\mathrm{p}<0.001, \mathrm{p}<0.01$, respectively), with $F$. cylindrus from the sea ice having the lowest relative content of amide II than all other diatoms $(\mathrm{p}<0.002$ for all comparisons). Fragilariopsis sp. from the open ocean did not differ from its pelagic partners, but had significantly more protein than Odontella sp., F. cylindrus and Chaetoceros sp. ( $p<0.001$ for all 3 ; Fig. 5F). For both saturated fatty acids (Fig. 5G) and saturated lipids (Fig. 5H), E. kjellmanii had significantly higher relative content than all other species ( $p<0.0001$ and $\mathrm{p}<0.0001$, respectively, for all comparisons). F. cylindrus was significantly lower in saturated fatty acids than the other sympagic algae and Fragilariopsis sp. from the pelagic environment $(\mathrm{p}<$ 0.030 for all comparisons), but was not lower than the other pelagic species (Fig. 5G), while Odontella sp. had significantly higher $(\mathrm{p}<0.001)$ saturated lipid content than Chaetoceros sp. (Fig. 5H). Unsaturated fatty acids were significantly higher in the sympagic algae, with highest content in Odontella sp. ( $\mathrm{p}<$ 0.003 for all comparisons expect E. kjellmanii), followed by E. kjellmanii, which was higher in unsaturated fatty acids than all 4 pelagic species $(\mathrm{p}<0.001$ for all comparisons; Fig. 5I). Unsaturated fatty acid was the only biomolecule to show any significant site effect $\left(F_{1,5}=11.96, \mathrm{p}=0.018\right)$, because of the higher mean content in the sympagic diatoms.

When pooled by site, the mean ratio of lipids to proteins showed significantly higher $\left(F_{1,5}=7.69, \mathrm{p}=\right.$ 0.039 ) relative lipid content in sympagic compared to pelagic diatoms (Fig. 6A). Carbohydrate to protein ratios did not differ significantly between sympagic and pelagic species, due to the high carbohydrate content in Fragilariopsis sp. from both sites (Fig. 6B). The unsaturated to saturated fatty acid ratio was significantly higher $\left(F_{1,4}=8.18, \mathrm{p}=0.046\right)$ in the sympagic than the pelagic diatoms (Fig. 6C).

\section{DISCUSSION}

In this study, the pelagic community was taxonomically diverse and representative of pelagic Southern Ocean coastal communities. The combined relative abundance of Phaeocystis antarctica and the diatoms 
Carbohydrates
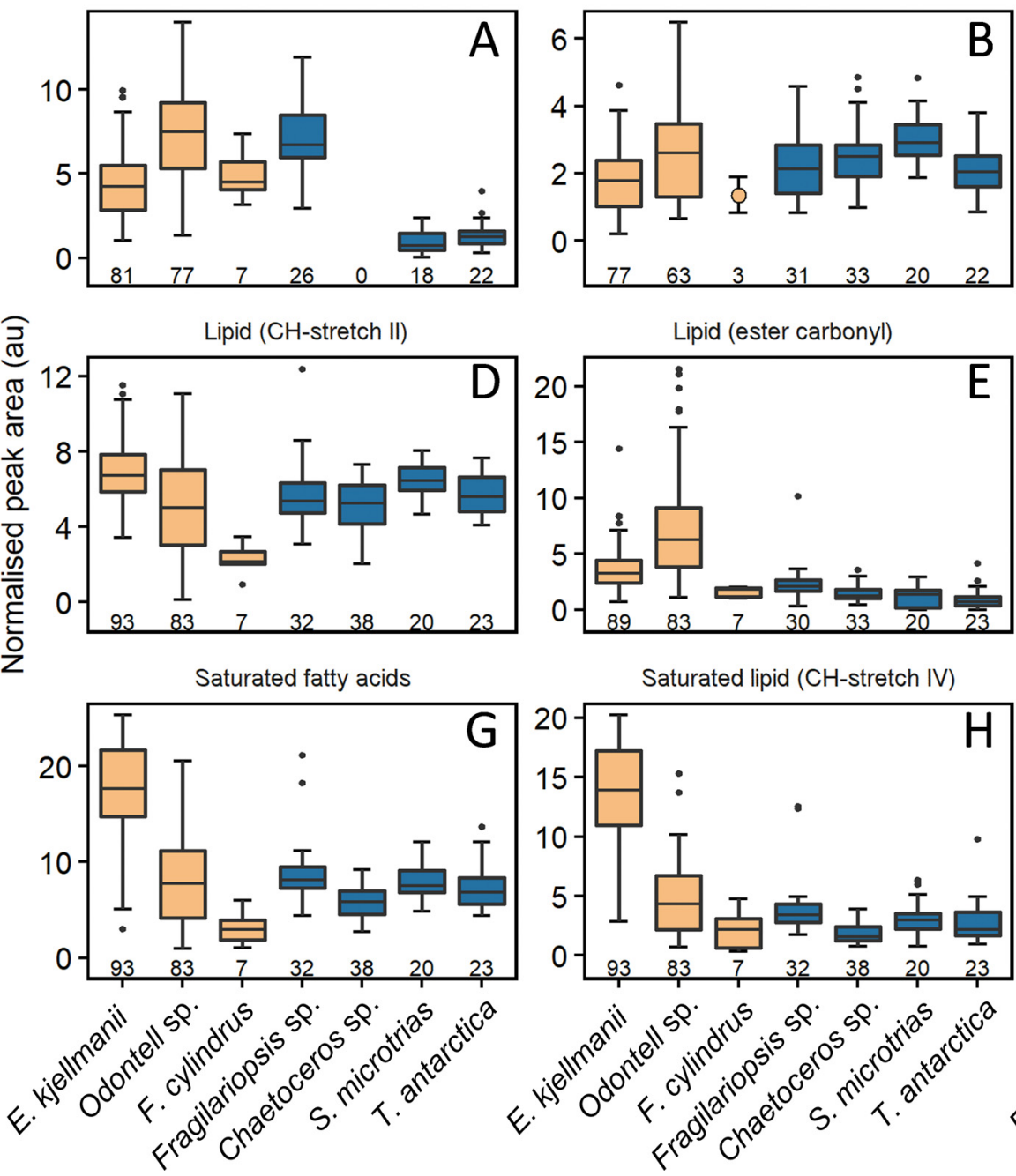

Carboxylates

Free amino acids
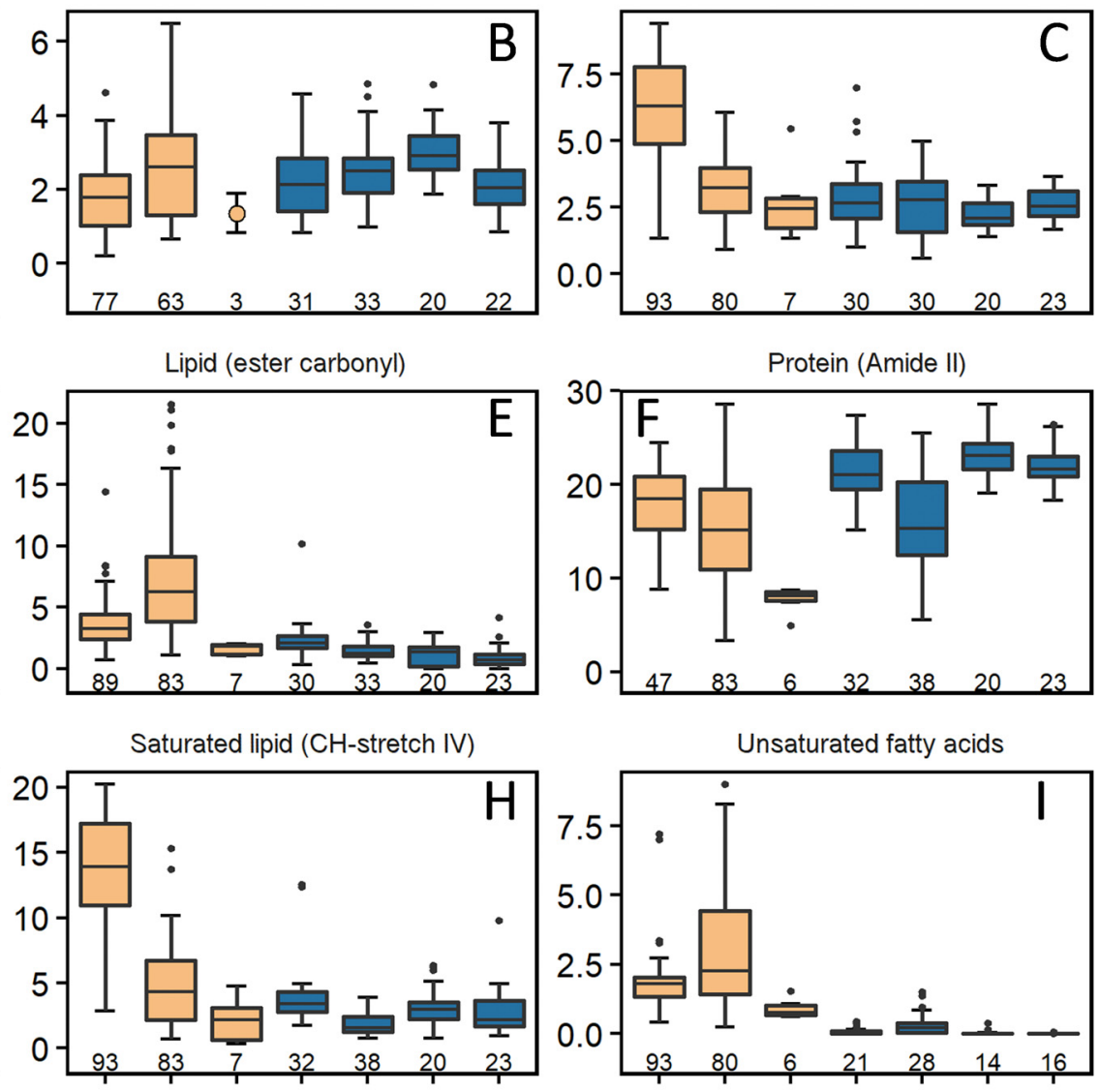

Fig. 5. Species-specific relative macromolecular content (based on normalised peak area) for selected pelagic (blue) and sympagic (orange) diatoms. Box and whisker plots show the IQR (box), the median value (horizontal black line), the minimum and maximum values (vertical lines) and outliers (dots). Numbers along the $x$-axes indicate number of spectra for each

species (n), peak areas are shown in arbitrary units (au)

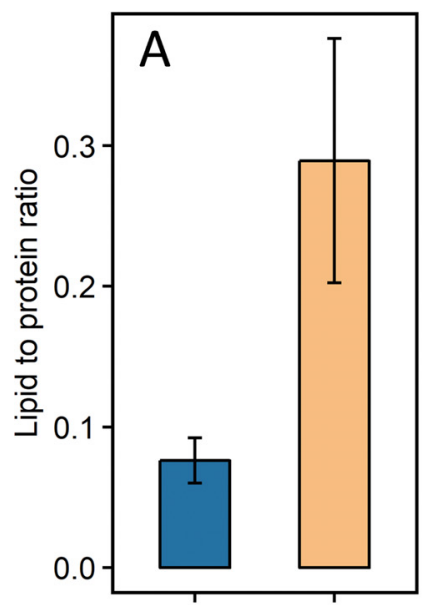

Pelagic Sympagic
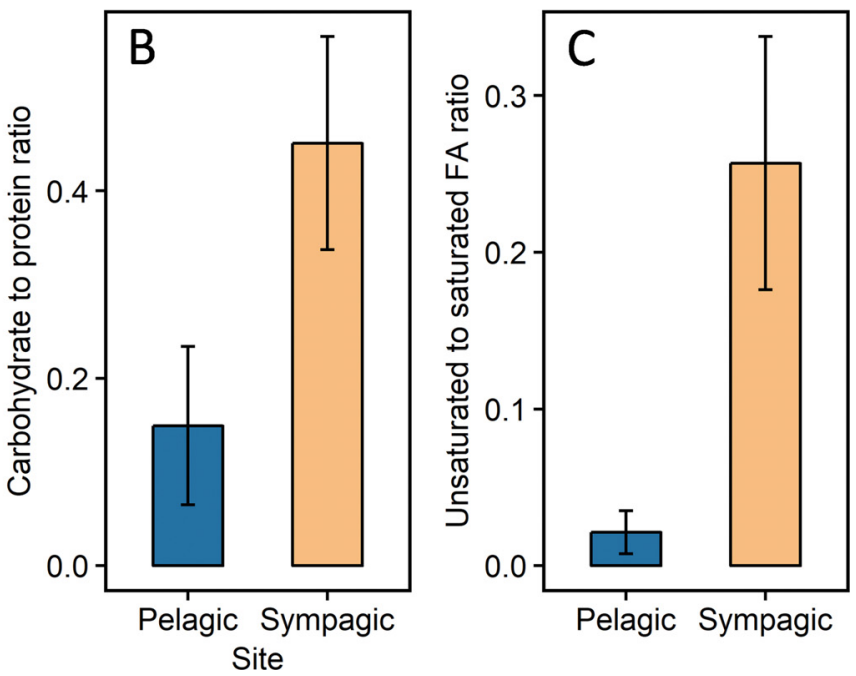

Fig. 6. Mean lipid, carbohydrate and fatty acid ratios of pelagic and sympagic diatoms. (A) Lipid to protein ratio based on the integrated peak areas of ester carbonyl (1745 $\mathrm{cm}^{-1}$ ) and amide II $\left(1545 \mathrm{~cm}^{-1}\right)$ bands. (B) Carbohydrate to protein ratio based on the integrated peak area of $\left(1175 \mathrm{~cm}^{-1}\right)$ and amide II $\left(1545 \mathrm{~cm}^{-1}\right)$. (C) Mean ratio of unsaturated $\left(3015 \mathrm{~cm}^{-1}\right)$ to saturated fatty acid $\left(\mathrm{FA}_{i} 2917 \mathrm{~cm}^{-1}\right)$. Data represent the mean $\pm \mathrm{SE}$ ratio of each species from each habitat (pelagic, $\mathrm{n}=4$; sympagic, $\mathrm{n}=3$ ) 
made up more than $50 \%$ of the community. These 2 groups are considered key species in Antarctic pelagic environments, with high correlations often observed between their respective biomass and water conditions (Arrigo et al. 1999, Garibotti et al. 2003a). The predominance of diatoms and Phaeocystis in the community is often attributed to their complementary yet contrasting photosynthetic strategies that allows for niche partitioning in the water column (Lavaud et al. 2007, Tang et al. 2009, Kropuenske et al. 2010). In this study, the primary productivity rate of the pelagic community was higher than the sympagic community, suggesting that higher diversity allows for greater physiological and spatial niche differentiation, which in turn may increase photosynthetic performance. While a sampling bias towards a diatom-only community as a result of lowered salinity during melting cannot be ruled out, the lower diversity, at both order and species levels, observed in the sympagic community is indicative of the physiological specialisation needed to occupy this habitat (Kottmeier \& Sullivan 1988, Thomas \& Dieckmann 2002). Similarly, the higher abundances yet lower diatom diversity in the sympagic community suggests that the late spring conditions of the sea ice, whilst perhaps not suited to a broad range of diatoms, selected for the few species that could establish and proliferate under those specific conditions. The sympagic community, despite having lower photosynthetic rates, did show comparatively high photoprotective capacity to high light, congruent with previous studies (Petrou et al. 2010, 2011b), thereby suggesting that the lower photosynthetic yields may be a result of changes in other energy metabolic processes that are necessary for maintaining cellular integrity, such as membrane stability via lipid production (Mock \& Kroon 2002b, Morgan-Kiss et al. 2006).

In order to adjust to the osmotic stress experienced during sea-ice formation, microalgae can modify their cellular concentrations of osmolytes (such as proline and glycine betaine), they can produce exopolymeric substances like glycoproteins that modify external environments (Krembs \& Deming 2008) or synthesise specialised amino acids for maintaining internal osmotic equilibrium (Krell 2006). To adjust to sub-zero temperatures, microalgae may increase concentrations of polyunsaturated fatty acids to assist with maintaining membrane fluidity (Morgan-Kiss et al. 2006) or increase production of ice-binding and antifreeze proteins, which prevent ice recrystallization and act as a cryoprotectant (Janech et al. 2006). It has been suggested that both pelagic and sea-ice microalgae use DMSP as a cryoprotectant and an osmolyte (Thomas \& Dieckmann 2002, Lyon et al. 2011), and given the high salinity and low temperature conditions of the sea-ice environment, we therefore anticipated to find higher DMSP concentrations in the sympagic community. Contrary to expectation, however, our results showed that DMSP was lower in the sympagic community, and that these values were much lower than previously published values (Trevena et al. 2000, Asher et al. 2011). Therefore, it cannot be ruled out that the changed conditions during the melting out of the microalgae from the ice may have resulted in alterations to DMSP production and retention by the cells (Van Bergeijk et al. 2003), leading to an underestimation of particulate DMSP. The DMSP measured in the pelagic sample was likely driven by the abundance of the prolific DMSP-producer Phaeocystis antarctica (>30\%), a species commonly studied for its role in DMSP cycling in Antarctic waters (Liss et al. 1994, Stefels \& Dijkhuizen 1996, van Leeuwe \& Stefels 1998, 2007, DiTullio et al. 2001). There would also have been some contribution to DMSP from dinoflagellates, which are commonly accepted as the most prolific producers of DMSP (Caruana et al. 2012, Caruana \& Malin 2014); however, this contribution was likely minimal, given that the relative abundance of dinoflagellates in the community was around $2 \%$. Recent research characterising DMSP production by Antarctic diatoms has shown that, unlike temperate diatoms, many polar pennate diatoms can produce moderate to high amounts of DMSP, with intracellular concentrations ranging from 3 to $57 \mathrm{mM}$ (Sheehan \& Petrou 2020). As such, it seems reasonable to assume that a proportion of the DMSP produced by the pelagic community could also be attributed to the high abundance of pennate diatoms. In general, the chl a specific DMSP concentrations obtained in this study are quite low compared with other studies (Galindo et al. 2016, Stefels et al. 2018), yet, for the pelagic community, the DMSP:chl a ratio was within range of those measured by Galindo et al. (2016) in under-ice communities (3.98 to 6.55) dominated by centric and pennate diatoms.

Our results on DMSP and DLA in the pelagic environment are congruent with the high production and conversion rate of DMSP commonly measured in Antarctic waters (Asher et al. 2011). Phaeocystis spp. possess DMSP lyases (Stefels \& van Boekel 1993, Stefels \& Dijkhuizen 1996, Harada \& Kiene 2011), enzymes responsible for cleaving DMSP to produce DMS, which have resulted in some of the highest concentrations of DMS recorded during blooms (Vance et al. 2013). As such, the higher rates of DLA 
measured here in the pelagic environment may be at least partly attributed to the dominance of $P$. antarctica. This contrasted with the lower DLA and DMSP turnover rate measured for the sympagic community compared to the pelagic environment $<<35$ and $\sim 60 \% \mathrm{~h}^{-1}$, respectively), suggesting a minimal role of DMSP within the sea-ice microbial community.

Microalgae, like many organisms, will adjust their macromolecular composition depending on temperature, nutrient and light conditions, influencing the nutritional quality and energy availability to higher trophic levels (Halsey \& Jones 2015). Despite the high similarity in macromolecular profiles of the diatoms from the pelagic community, some differences, possibly based on cell type (pennate vs. discoid centric), were evident. For example, the pennate diatom Fragilariopsis sp. was differentiated by having the highest carbohydrate, lipids and saturated fatty acid content, while macromolecular profiles of the 2 discoid centric diatoms Stellarima microtrias and Thalassiosira antarctica, which were tightly grouped, separated from the other 2 species by having the highest protein content. Due to the unique morphology of diatoms and the restriction of cytoplasm to a thin parietal layer inside the frustule, a negative relationship between cellular concentrations of carbohydrate and cell volume has been previously recorded (Hitchcock 1982), which would support the lower relative carbohydrate content found in the 2 larger diatom species. However, in general, as diatoms increase in size, they increase the number and volume of vacuoles, and therefore this size-dependent vacuolation results in minimal size scaling of protein and lipids with cell volume (Finkel et al. 2016a). Instead, as a phylogenetic group, diatoms are generally high in lipid and low in carbohydrates when compared with other phytoplankton (Finkel et al. 2016b), making them an energy-rich food source for the polar foodweb.

Lipids are the most energy rich macromolecules, with an energy storage capacity of $39.4 \mathrm{~J} \mathrm{mg}^{-1}$, compared with just 23.6 and $17.2 \mathrm{~J} \mathrm{mg}^{-1}$ for proteins and carbohydrates, respectively (Hagen \& Auel 2001). In this study, we found the lipid content of the sea-ice community was relatively high in both saturated and unsaturated fatty acids, particularly for E. kjellmanii and Odontella sp. These results are consistent with previous studies (Fahl \& Kattner 1993, Mock \& Kroon 2002a,b, Pogorzelec et al. 2017), as environmental conditions of sea ice are known to induce high concentrations of polyunsaturated fatty acids, especially during winter (Thomas \& Dieckmann 2002) or late spring when nutrients become limiting (Pogorzelec et al. 2017). The high calorific value of lipids makes them important for sustaining energy-hungry food webs, and any shift in community composition or macromolecular stores away from high lipid microalgae could affect the number of calories available to those higher trophic levels. While lipids are a great source of energy for consumers, for the producer, not all lipids are equal. Saturated fatty acids are mainly used for energy storage, whereas unsaturated fatty acids are important in physiological processes and membrane fluidity (Brett \& Müller Navarra 1997). We found that sympagic diatoms were higher in unsaturated fatty acid content compared with pelagic diatoms, suggesting a preferential investment in unsaturated fatty acids, possibly to ensure that membrane fluidity is maintained during freezing. Equally, the difference could be attributed to habitat-related nutrient conditions, whereby summer sea-ice algae living at or above the ice-water interface are often nutrient limited (Dieckmann et al. 1991, McMinn et al. 1999) compared with pelagic species that are readily mixed within the water column. Nutrient limitation, which has been shown to induce high lipid production in microalgae (Pogorzelec et al. 2017), could potentially account for the heavy investment into lipids, while also enhancing survival at low temperatures. Ecologically, a high unsaturated fatty acid content in microalgae is important in the maintenance of high growth, survival and reproductive rates in zooplankton grazers (Brett \& Müller Navarra 1997, Demott \& Müller-Navarra 1997), supporting the idea that sympagic diatoms provide an essential high energy source for Antarctic marine ecosystems. Given that sea-ice algae are a main source of food for zooplankton during spring (Thomas \& Dieckmann 2002), if our single time point 'snap shot' of macromolecular data is representative of the greater ecosystem, the differences in macromolecular content measured here likely underpin the food quality that is transferred through the trophic web, which in turn may be key to the productivity of the Antarctic marine ecosystem.

We found species-specific signatures in the macromolecular profiles, highlighting the variation in cellular levels of major classes of macromolecules (lipids, proteins and carbohydrates) in response to environmental conditions. For example, within the sea-ice community, E. kjellmanii and Odontella sp. had greater relative amounts of lipids (predominantly saturated fatty acids) than F. cylindrus. Similarly, there were significant variations in protein and carbohydrates between species from the pelagic environment. These results match previous work, 
which found variation in macromolecular composition to be species-specific, with species responding differentially despite the same environmental conditions (Sackett et al. 2013). These species-specific physiological trade-offs between photosynthesis, resource allocation and growth, are what underpin niche differentiation and productivity in the marine ecosystem and suggest that overall phytoplankton community composition may significantly affect the energy available for higher trophic levels. Lipid dynamics of Antarctic krill, such as Euphasia super$b a$, are strongly influenced by season. Adult krill will accumulate large lipid reserves during summer, following heavy sea-ice feeding during spring, with a peak in April and May, that become progressively depleted over the winter reaching a minimum in early spring (Hagen \& Auel 2001). As such, lipids obtained from pulsed productivity events in the late spring (sympagic) and summer (pelagic) play a critical role in the overwintering strategy for energy storage of Antarctic herbivores. These high-energy compounds, which are indispensable to krill, are also essential for supporting stocks of marine mammals and birds in Antarctica.

This study characterised the productivity, sulfur biochemistry and macromolecular composition of Antarctic microalgae from 2 marine habitats. Here, the pelagic community was characterised by higher diversity and productivity, higher DMSP content and lyase activity, as well as diatoms that showed elevated levels of proteins compared with those from the sea ice. The key characteristics of the sympagic community, dominated by diatoms, was lower overall productivity and sulfur biochemistry, but high levels of photoprotection, demonstrating strong resilience to photoinhibition. Most notably, on average, the sympagic diatoms had higher unsaturated and saturated fatty acid content compared to their pelagic neighbours, which suggests that sympagic microalgae are a particularly high-calorie food source and as such, an essential pool of energy to rapidly re-fuel the Antarctic foodweb after the long starvation over the winter. While the macromolecular profiles were limited to a few species, and only diatoms, the strength of the single-celled analyses lies in providing quantitative information on the contribution of each species to trophic energy. In this way, it becomes possible to identify important species for krill survival and development, and equally, to understand how altered community structure may influence the nutritional value of food sources and thereby trophic efficiency in the Antarctic marine foodweb.
Acknowledgements. We thank the Australian Synchrotron Principal Beamline Scientists Drs. Mark Tobin and Jitraporn Vongsvivut for technical support in synchrotron IR microspectroscopy data acquisition. Part of this work was funded by the Australian Synchrotron through merit-based beamtime awarded on the Infrared Microscopy (IRM) beamline (AS153/IRM/10005). Thanks also to Dr. Andrew Davidson and the Australian Antarctic Division for field support and sample collection as part of the Australian Antarctic Science Project 4026 and to Dr. Alyce Hancock for cell counts of the pelagic community. C.E.S. was supported by an Australian Postgraduate Award (APA), and research funding was provided by the Climate Change Cluster (C3) and the School of Life Science, University of Technology Sydney.

\section{LITERATURE CITED}

Arrigo KR (2005) Marine microorganisms and global nutrient cycles. Nature 437:349-355

Arrigo KR, Robinson DH, Worthen DL, Dunbar RB, DiTullio GR, VanWoert M, Lizotte MP (1999) Phytoplankton community structure and the drawdown of nutrients and $\mathrm{CO}_{2}$ in the Southern Ocean. Science 283:365-367

Asher EC, Dacey JWH, Mills MM, Arrigo KR, Tortell PD (2011) High concentrations and turnover rates of DMS, DMSP and DMSO in Antarctic sea ice. Geophys Res Lett 38:L23609

Bowler C, Allen AE, Badger JH, Grimwood J and others (2008) The Phaeodactylum genome reveals the evolutionary history of diatom genomes. Nature 456:239-244

Brett M, Müller Navarra D (1997) The role of highly unsaturated fatty acids in aquatic foodweb processes. Freshw Biol 38:483-499

Buesseler KO (1998) The decoupling of production and particulate export in the surface ocean. Global Biogeochem Cycles 12:297-310

Carnat G, Brabant F, Dumont I, Vancoppenolle M and others (2016) Influence of short-term synoptic events and snow depth on DMS, DMSP, and DMSO dynamics in Antarctic spring sea ice. Elementa Sci Anthropocene 4: 000135

Caruana AMN, Malin G (2014) The variability in DMSP content and DMSP lyase activity in marine dinoflagellates. Prog Oceanogr 120:410-424

Caruana AMN, Steinke M, Turner SM, Malin G (2012) Concentrations of dimethylsulphoniopropionate and activities of dimethylsulphide-producing enzymes in batch cultures of nine dinoflagellate species. Biogeochemistry 110:87-107

* Damm E, Nomura D, Martin A, Dieckmann GS, Meiners KM (2016) DMSP and DMS cycling within Antarctic sea ice during the winter-spring transition. Deep Sea Res II 131: 150-159

* Demott W, Müller-Navarra D (1997) The importance of highly unsaturated fatty acids in zooplankton nutrition: evidence from experiments with Daphnia, a cyanobacterium and lipid emulsions. Freshw Biol 38:649-664

* Deppeler S, Petrou K, Schulz KG, Westwood K, Pearce I, McKinlay J, Davidson A (2018) Ocean acidification of a coastal Antarctic marine microbial community reveals a critical threshold for $\mathrm{CO}_{2}$ tolerance in phytoplankton productivity. Biogeosciences 15:209-231 
Dieckmann GS, Lange MA, Ackley SF, Jennings JC Jr (1991) The nutrient status in sea ice of the Weddell Sea during winter: effects of sea ice texture and algae. Polar Biol 11:449-456

DiTullio GR, Sedwick PN, Jones DR, Boyd PW, Crossley AC, Hutchins DA (2001) Effects of iron, silicate, and light on dimethylsulfoniopropionate production in the Australian Subantarctic Zone. J Geophys Res 106:31585-531595

Fahl K, Kattner G (1993) Lipid content and fatty acid composition of algal communities in sea-ice and water from the Weddell Sea (Antarctica). Polar Biol 13:405-409

Falkowski PG, LaRoche J (1991) Acclimation to spectral irradiance in algae. J Phycol 27:8-14

Finkel ZV, Follows MJ, Irwin AJ (2016a) Size-scaling of macromolecules and chemical energy content in the eukaryotic microalgae. J Plankton Res 38:1151-1162

Finkel ZV, Follows MJ, Liefer JD, Brown CM, Benner I, Irwin AJ (2016b) Phylogenetic diversity in the macromolecular composition of microalgae. PLOS ONE 11: e0155977

Follows MJ, Dutkiewicz S (2011) Modeling diverse communities of marine microbes. Annu Rev Mar Sci 3:427-451

Gabric A, Matrai P, Jones G, Middleton J (2018) The nexus between sea ice and polar emissions of marine biogenic aerosols. Bull Am Meteorol Soc 99:61-81

Galindo V, Levasseur M, Mundy CJ, Gosselin M and others (2014) Biological and physical processes influencing sea ice, under-ice algae, and dimethylsulfoniopropionate during spring in the Canadian Arctic Archipelago. J Geophys Res Oceans 119:3746-3766

Galindo V, Levasseur M, Mundy CJ, Gosselin M and others (2016) Contrasted sensitivity of DMSP production to high light exposure in two Arctic under-ice blooms. J Exp Mar Biol Ecol 475:38-48

Garibotti IA, Vernet M, Ferrario ME, Smith RC, Ross RM, Quetin LB (2003a) Phytoplankton spatial distribution patterns along the western Antarctic Peninsula (Southern Ocean). Mar Ecol Prog Ser 261:21-39

Garibotti IA, Vernet M, Kozlowski WA, Ferrario ME (2003b) Composition and biomass of phytoplankton assemblages in coastal Antarctic waters: a comparison of chemotaxonomic and microscopic analyses. Mar Ecol Prog Ser 247: $27-42$

Garrison DL, Buck KR (1986) Organism losses during ice melting: a serious bias in sea ice community studies. Polar Biol 6:237-239

Giordano M, Kansiz M, Heraud P, Beardall J, Wood B, McNaughton D (2001) Fourier transform infrared spectroscopy as a novel tool to investigate changes in intracellular macromolecular pools in the marine microalgal Chaetoceros muellerii (Bacillariophyceae). J Phycol 37: 271-279

* Gleitz M, Thomas DN (1992) Physiological responses of a small Antarctic diatom (Chaetoceros sp.) to simulated environmental constraints associated with sea-ice formation. Mar Ecol Prog Ser 88:271-278

*Hagen W, Auel H (2001) Seasonal adaptations and the role of lipids in oceanic zooplankton. Zoology 104:313-326

*Hagen W, Van Vleet ES, Kattner G (1996) Seasonal lipid storage as overwintering strategy of Antarctic krill. Mar Ecol Prog Ser 134:85-89

Halsey KH, Jones BM (2015) Phytoplankton strategies for photosynthetic energy allocation. Annu Rev Mar Sci 7: 265-297
Hancock AM, Davidson AT, McKinley J, McMinn A, Schulz KG, van den Enden RL (2018) Ocean acidification changes the structure of an Antarctic coastal protistan community. Biogeosci Discuss 15:2393-2410

* Harada H, Kiene RP (2011) Assessment and characteristics of DMSP lyase activity in seawater and phytoplankton cultures. Publ Seto Mar Biol Lab 41:1-16

*Harada H, Rouse MA, Sunda W, Kiene RP (2004) Latitudinal and vertical distributions of particle-associated dimethylsulfoniopropionate (DMSP) lyase activity in the western North Atlantic Ocean. Can J Fish Aquat Sci 61: 700-711

*Hitchcock GL (1982) A comparative study of the sizedependent organic composition of marine diatoms and dinoflagellates. J Plankton Res 4:363-377

Janech MG, Krell A, Mock T, Kang JS, Raymond JA (2006) Ice-binding proteins from sea ice diatoms (Bacillariophyceae). J Phycol 42:410-416

Jeffrey SW, Humphrey GF (1975) New spectrophotometric equations for determining chlorophyll $a, b, c_{1}$, and $c_{2}$ in higher plants and natural phytoplankton. Biochem Physiol Pflanz 167:191-194

Keller MD (1989) Dimethyl sulfide production and marine phytoplankton: the importance of species composition and cell size. Biol Oceanogr 6:375-382

Kottmeier ST, Sullivan CW (1988) Sea ice microbial communities (SIMCO). Polar Biol 8:293-304

Krell A (2006) Salt stress tolerance in the psychrophilic diatom Fragilariopsis cylindrus. PhD thesis, University of Bremen

Krembs C, Deming JW (2008) The role of exopolymers in microbial adaptation to sea ice. In: Margesin R, Schinner F, Marx JC, Gerday C (eds) Psychrophiles: from biodiversity to biotechnology. Springer, Berlin, p 247-264

Kropuenske LR, Mills MM, van Dijken GL, Bialey S, Robinson DH, Welschmeyer NA, Arrigo KR (2009) Photophysiology in two major Southern Ocean phytoplankton taxa: photoprotection in Phaeocystis antarctica and Fragilariopsis cylindrus. Limnol Oceanogr 54:1176-1196

Kropuenske LR, Mills MM, van Dijken GL, Alderkamp AC and others (2010) Strategies and rates of photoacclimation in two major Southern Ocean phytoplankton taxa: Phaeocystis antarctica (Haptophyta) and Fragilariopsis cylindrus (Bacillariophyceae). J Phycol 46:1138-1151

* Lavaud J, Strzepek RF, Kroth PG (2007) Photoprotection capacity differs among diatoms: possible consequences on the spatial distribution of diatoms related to fluctuations in the underwater light climate. Limnol Oceanogr 52:1188-1194

Kiss PS, Malin G, Turner SM, Holligan PM (1994) Dimethyl sulphide and Phaeocystis: a review. J Mar Syst 5:41-53

* Lyon BR, Lee PA, Bennett JM, DiTullio GR, Janech MG (2011) Proteomic analysis of a sea-ice diatom: Salinity acclimation provides new insight into the dimethylsulfoniopropionate production pathway. Plant Physiol 157: 1926-1941

* MacIntyre HL, Kana TM, Anning T, Geider RJ (2002) Photoacclimation of photosynthesis irradiance response curves and photosynthetic pigments in microalgae and cyanobacteria. J Phycol 38:17-38

*McMinn A, Skerratt J, Trull T, Ashworth C, Lizotte M (1999) Nutrient stress gradient in the bottom $5 \mathrm{~cm}$ of fast ice, McMurdo Sound, Antarctica. Polar Biol 21:220-227

Mills MM, Kropuenske LR, van Dijken GL, Alderkamp AC 
and others (2010) Photophysiology in two Southern Ocean phytoplankton taxa: photosynthesis of Phaeocystis antarctica (Prymnesiophyceae) and Fragilariopsis cylindrus (Bacillariophyceae) under simulated mixedlayer irradiance. J Phycol 46:1114-1127

Mock T, Hoch N (2005) Long-term temperature acclimation of photosynthesis in steady-state cultures of the polar diatom Fragilariopsis cylindrus. Photosynth Res 85:307-317

Mock T, Kroon BMA (2002a) Photosynthetic energy conversion under extreme conditions - I: important role of lipids as structural modulators and energy sink under N-limited growth in Antarctic sea ice diatoms. Phytochemistry 61: 41-51

* Mock T, Kroon BMA (2002b) Photosynthetic energy conversion under extreme conditions - II: the significance of lipids under light limited growth in Antarctic sea ice diatoms. Phytochemistry 61:53-60

Moore CM, Mills MM, Arrigo KR, Berman-Frank I and others (2013) Processes and patterns of oceanic nutrient limitation. Nat Geosci 6:701-710

Morgan-Kiss RM, Priscu JC, Pocock T, Gudynaite-Savitch L, Huner NPA (2006) Adaptation and acclimation of photosynthetic microorganisms to permanently cold environments. Microbiol Mol Biol Rev 70:222-252

* Murdock JN, Wetzel DL (2009) FT-IR microspectroscopy enhances biological and ecological analysis of algae. Appl Spectrosc Rev 44:335-361

* Petrou K, Hill R, Brown CM, Campbell DA, Doblin MA, Ralph PJ (2010) Rapid photoprotection in sea-ice diatoms from the East Antarctic pack ice. Limnol Oceanogr 53: 1400-1407

Petrou K, Doblin MA, Ralph PJ (2011a) Heterogeneity in the photoprotective capacity of three Antarctic diatoms during short-term changes in salinity and temperature. Mar Biol 158:1029-1041

* Petrou K, Hill R, Doblin MA, McMinn A, Johnson R, Wright SW, Ralph PJ (2011b) Photoprotection of sea ice microalgal communities from the East Antarctic pack ice. J Phycol 47:77-86

* Petrou K, Baker KG, Nielsen DA, Hancock AM, Schulz KG, Davidson AT (2019) Acidification diminishes diatom silica production in the Southern Ocean. Nat Clim Chang 9: 781-796

* Pogorzelec NM, Mundy CJ, Findlay CR, Campbell K and others (2017) FTIR imaging analysis of cell content in seaice diatom taxa during a spring bloom in the lower Northwest Passage of the Canadian Arctic. Mar Ecol Prog Ser 569:77-88

R Development Core Team (2018) R: a language and environment for statistical computing. R Foundation for Statistical Computing, Vienna

* Ralph PJ, Gademann R (2005) Rapid light curves: a powerful tool to assess photosynthetic activity. Aquat Bot 82: 222-237

Ritchie RJ (2006) Consistent sets of spectrophotometric chlorophyll equations for acetone, methanol and ethanol solvents. Photosynth Res 89:27-41

Sackett O, Petrou K, Reedy B, De Grazia A and others (2013) Phenotypic plasticity of southern ocean diatoms: key to success in the sea ice habitat? PLOS ONE 8:e81185

Sheehan CE, Petrou K (2020) Dimethylated sulfur production in batch cultures of Southern Ocean phytoplankton. Biogeochemistry 147:53-69
Stefels J (2000) Physiological aspects of the production and conversion of DMSP in marine algae and higher plants. J Sea Res 43:183-197

K Stefels J, Dijkhuizen L (1996) Characteristics of DMSP-lyase in Phaeocystis sp. (Prymnesiophyceae). Mar Ecol Prog Ser 131:307-313

* Stefels J, van Boekel WHM (1993) Production of DMS from dissolved DMSP in axenic cultures of the marine phytoplankton species Phaeocystis sp. Mar Ecol Prog Ser 97: $11-18$

K Stefels J, van Leeuwe MA, Jones EM, Meredith MP, Venables HJ, Webb AL, Henley SF (2018) Impact of sea-ice melt on dimethyl sulfide (sulfoniopropionate) inventories in surface waters of Marguerite Bay, West Antarctic Peninsula. Philos Trans R Soc A 376:20170169

Stevens A, Ramirez-Lopez L (2013) An introduction to the prospectr package. R package version 013. https://CRAN. R-project.org/package=prospectr

* Tang KW, Smith WO, Shields AR, Elliott DT (2009) Survival and recovery of Phaeocystis antarctica (Prymnesiophyceae) from prolonged darkness and freezing. Proc R Soc B 276:81-90

Tapiolas DM, Raina JB, Lutz A, Willis BL, Motti CA (2013) Direct measurement of dimethylsulfoniopropionate (DMSP) in reef-building corals using quantitative nuclear magnetic resonance (qNMR) spectroscopy. J Exp Mar Biol Ecol 443:85-89

Thomas DN, Dieckmann GS (2002) Antarctic sea icea habitat for extremophiles. Science 295:641-644

* Tobin MJ, Puskar L, Barber RL, Harvey EC and others (2010) FTIR spectroscopy of single live cells in aqueous media by synchrotron IR microscopy using microfabricated sample holders. Vib Spectrosc 53:34-38

* Tréguer PJ, De La Rocha CL (2013) The world ocean silica cycle. Annu Rev Mar Sci 5:477-501

* Tréguer P, Bowler C, Moriceau B, Dutkiewicz S and others (2018) Influence of diatom diversity on the ocean biological carbon pump. Nat Geosci 11:27-37

* Trevena AJ, Jones GB (2006) Dimethylsulphide and dimethylsulphoniopropionate in Antarctic sea ice and their release during sea ice melting. Mar Chem 98: 210-222

* Trevena AJ, Jones GB, Wright S, van den Enden RL (2000) Profiles of DMSP, algal pigments, nutrients and salinity in pack ice from eastern Antarctica. J Sea Res 43: 256-273

*Van Bergeijk SA, Van der Zee C, Stal LJ (2003) Uptake and excretion of dimethylsulphoniopropionate is driven by salinity changes in the marine benthic diatom Cylindrotheca closterium. Eur J Phycol 38:341-349

* van Leeuwe MA, Stefels J (1998) Effects of iron and light stress on the biochemical composition of Antarctic Phaeocystis sp. (Prymnesiophyceae). II. Pigment composition. J Phycol 34:496-503

*van Leeuwe MA, Stefels J (2007) Photosynthetic responses in Phaeocystis antarctica towards varying light and iron conditions. Biogeochemistry 83:61-70

* Vance TR, Davidson AT, Thomson PG, Levasseur M, Lizotte M, Curran MAJ, Jones GB (2013) Rapid DMSP production by an Antarctic phytoplankton community exposed to natural surface irradiances in late spring. Aquat Microb Ecol 71:117-129

Villareal TA, Fryxell GA (1983) Temperature effects on the valve structure of the bipolar diatoms Thalassiosira ant- 
arctica and Porosira glacialis. Polar Biol 2:163-169

Vongsvivut J, Heraud P, Zhang W, Kralovec JA, McNaughton DM, Barrow CJ (2012) Quantitative determination of fatty acid compositions in micro-encapsulated fish-oil supplements using Fourier transform infrared (FTIR) spectroscopy. Food Chem 135:603-609

Wagner H, Liu Z, Langner U, Stehfest K, Wilhelm C (2010)

Editorial responsibility: Antonio Bode, A Coruña, Spain
The use of FTIR spectroscopy to assess quantitative changes in the biochemical composition of microalgae. J Biophotonics 3:557-566

Wagner H, Jakob T, Fanesi A, Wilhelm C (2017) Towards an understanding of the molecular regulation of carbon allocation in diatoms: the interaction of energy and carbon allocation. Philos Trans R Soc B 372:20160410

Submitted: September 25, 2019; Accepted: March 23, 2020 Proofs received from author(s): April 17, 2020 